\title{
Lithiated cobaltates for lithium-ion batteries: Structure, morphology and electrochemistry of oxides grown by solid-state reaction, wet chemistry and film deposition
}

\author{
C. Julien, S. Gastro-Garcia \\ Laboratoire des Milieux Désordonnés et Hétérogènes, UMR 7603, Université \\ Pierre et Marie Curie, 4 place Jussieu, case 86, 75252 Paris Cedex 05, France
}

Journal of Power Sources

Volumes 97-98, July 2001, Pages 290-293

Proceedings of the 10th International Meeting on Lithium Batteries

Received 21 June 2000, Accepted 6 January 2001, Available online 3 July 2001

doi:10.1016/S0378-7753(01)00676-0

\begin{abstract}
We present the structural (XRD and Raman) and electrochemical properties of various oxides of the cobaltate family (with the $\alpha-\mathrm{NaFeO}_{2}$-type structure) grown by solid-state reaction, wet chemistry and film deposition techniques. It is shown that synthesis greatly affects the electrochemistry and cycle life characteristics of these layer structured cathode materials. HT-LiCoO $2, \quad \mathrm{LT}-\mathrm{LiCoO}_{2}$, doped $\mathrm{LiCO}_{1-} y \mathrm{Aly} \mathrm{O}_{2}$ and $\mathrm{LiCoO}_{2}$ films are investigated.
\end{abstract}

Keywords

Cobaltate; Lithium-ion battery; Solid-state reaction 


\section{Introduction}

Compounds with the $\alpha-\mathrm{NaFeO}_{2}$-type structure $\left(\mathrm{R}_{\overline{3}} \mathrm{~m}\right)$ are widely studied in search of their structural stability and improved electrochemical performance for cathode materials in rechargeable lithium-ion batteries [1], [2], [3], [4] and [5]. Physico-chemical properties of $\mathrm{LiCoO}_{2}$ can be summarized as follows. (i) Open circuit voltages of 3.5$4.5 \mathrm{~V}$ for $\mathrm{Lix} \mathrm{CoO}_{2} \square \mathrm{Li}$ cells are consistent with the oxidizing power of the $\mathrm{Co}^{4+} / \mathrm{Co}^{3+}$ couple. (ii) The high $\mathrm{Li}^{+}$-ion mobility is relative to the spacing between oxygen layers facing the $\mathrm{Li}$ layers and the high electron affinity of the low-spin $\mathrm{Co}(\mathrm{IV}) / \mathrm{Co}$ (III) couple, which makes the oxygen layers strongly polarizable toward the cobalt layers. (iii) Some limitations due to its expensive technology, toxicity, cycle life failure, and coexistence of two phases are a debatable subject in using $\mathrm{LixCoO}$, i.e. a critical composition in terms of cycle life failure seems to be at about $x=1 / 2$, at which a monoclinic phase is observed. (iv) When the $\mathrm{Li} \square \mathrm{LiCoO}_{2}$ cell is cycled over the limited composition range $0.5<x<1.0$, rechargeability and capacity retention are fairly good. The practical characteristics of $\mathrm{LiCoO}_{2}$ as a cathode material also depend on extrinsic properties, such as particle size and electrode porosity, and hence on the growth method.

In this work, we present the structural and electrochemical properties of various oxides of the cobaltate family grown by solid-state reaction, wet chemistry and film deposition techniques. It is shown that synthesis greatly affects their electrochemistry and cycle life characteristics.

\section{Synthesis and structure of cathode materials}

High-temperature samples of $\mathrm{LiCo}_{1-} y \mathrm{AlyO}_{2}$ were synthesized by direct reaction of $\mathrm{LiOH}, \mathrm{y}-\mathrm{LiAlO}_{2}$, and $\mathrm{Co}_{3} \mathrm{O}_{4}$. The homogenous mixture of the powders were packed in a shallow ceramic boat and heat treated at $450^{\circ} \mathrm{C}$ (melting point of $\mathrm{LiOH}$ ) for $8 \mathrm{~h}$ under a flow of oxygen. Lithium cobaltate powders were also synthesized by wet chemistry method according to the sol-gel procedure reported elsewhere [6] and [7]. Pulsed laser deposited (PLD) $\mathrm{LiCoO}_{2}$ films were grown onto silicon wafers from targets which were a mixture of $\mathrm{LiCoO}_{2}$ powder and variable amounts of $\mathrm{Li}_{2} \mathrm{O}$ additive $(0 \leq z \leq 15 \%)$. Thin-film deposition was performed in an oxygen atmosphere $\left(50 \leq P\left(\mathrm{O}_{2}\right) \leq 300 \mathrm{mTorr}\right)$ at different substrate temperatures from $\mathrm{RT}$ to $300^{\circ} \mathrm{C}[8]$.

XRD patterns of $\mathrm{LiCoO}_{2}$ and $\mathrm{LiCo}_{1}-y \mathrm{Aly} \mathrm{O}_{2}$ microcrystalline powders prepared by wet chemistry with a calcination at $800^{\circ} \mathrm{C}$ for $4 \mathrm{~h}$ in air indicate a pure phase. They are 
dominated by a strong Bragg peak located at ca. $2 \theta=19^{\circ}$ and Bragg peaks with medium intensity at 36 and $44^{\circ}$. Considering the intensity and position of the Bragg peaks, it is well known that patterns of the rhombohedral unit cell ( $\mathrm{R}_{\overline{3}} \mathrm{~m}$ space group) can be indexed in the hexagonal system. Unit-cell parameters are $a_{\text {hex }}=2.83 \AA$ and $c_{\text {hex }}=14.09 \AA$ for $\mathrm{LiCoO}_{2}$. Powders exhibit XRD patterns with quite well-defined doublets $(006,102)$ and $(108,110)$ when calcined at $800^{\circ} \mathrm{C}$ for $4 \mathrm{~h}$. The c/a ratio $(c / a=4.98)$ was different from the critical value 4.90 and the splitting of the $(006)$ and $\left(\begin{array}{lll}1 & 0 & 2\end{array}\right)$ as well as $\left(\begin{array}{lll}1 & 0 & 8\end{array}\right)$ and $\left(\begin{array}{lll}1 & 1 & 0\end{array}\right)$ diffraction lines indicate, as far as XRD measurements are concerned, the stabilization of the 2D structure and an ordered distribution of lithium and transition-metal ions in the lattice.

XRD patterns of $\mathrm{LiCoO}_{2}$ films grown onto $\mathrm{Si}$ wafer maintained at $T_{\mathrm{s}}=300^{\circ} \mathrm{C}$ in $P\left(\mathrm{O}_{2}\right)=100$ mTorr using a target without $\mathrm{Li}_{2} \mathrm{O}$ additive display the presence of cobalt oxide impurities. As the amount of $\mathrm{Li}_{2} \mathrm{O}$ increased in the target, the XRD patterns develop features expected for the regular layered phase. They are indexed using the $\mathrm{R}_{\overline{3}} \mathrm{~m}$ space group. Highly textured $\left(\begin{array}{lll}0 & 0 & 3\end{array}\right)$ films were obtained when a target with $15 \% \mathrm{Li}_{2} \mathrm{O}$ was used. The polycrystalline layered phase in $\mathrm{LiCoO}_{2}$ films appears upon increasing the substrate temperature up to $300^{\circ} \mathrm{C}$ in oxygen partial pressure $P\left(\mathrm{O}_{2}\right)=50$ mTorr using a lithium-rich target[8].

Nano-domain formation and change in cation ordering has been observed by local probes such as FTIR and Raman scattering (RS) spectroscopy, that are complementary tools for XRD [9] and [10]. As an example, the polarized RS spectra of $\mathrm{LiCoO}_{2}$ films deposited onto $\mathrm{Si}$ maintained at $300^{\circ} \mathrm{C}$ in oxygen partial pressure $P\left(\mathrm{O}_{2}\right)=50$ mTorr is shown in Fig. 1. Besides the Raman-active mode of the $\mathrm{Si}$ wafer (centered at $521 \mathrm{~cm}^{-1}$ ) the experimental RS data consist of a series of broad bands located between 400 and $700 \mathrm{~cm}^{-1}$. The RS peak positions at 484 and $594 \mathrm{~cm}^{-1}$ of PLD $\mathrm{LiCoO}_{2}$ films are in good agreement with those reported for the $\mathrm{LiCoO}_{2}$ crystal. The vibrational signature of the $\mathrm{LiCoO}_{2}$ matches well with the two allowed Raman modes. The peak located at $693 \mathrm{~cm}^{-1}$ indicates the presence of $\mathrm{Co}_{3} \mathrm{O}_{4}$ impurities in the film. The formation of $\mathrm{Co}_{3} \mathrm{O}_{4}$ is related to lithium loss during the deposition process. To compensate this loss we have prepared films from lithium-rich targets including addition of $5-15 \%$ of $\mathrm{Li}_{2} \mathrm{O}$. The corresponding spectra display a substantial decrease of the peak at $693 \mathrm{~cm}^{-1}$ indicating the vanish of $\mathrm{Co}_{3} \mathrm{O}_{4}$ species upon addition of $\mathrm{Li}_{2} \mathrm{O}$. The optimum amount of $\mathrm{Li}_{2} \mathrm{O}$ to compensate the lithium loss lies between 10 and $15 \%$. 


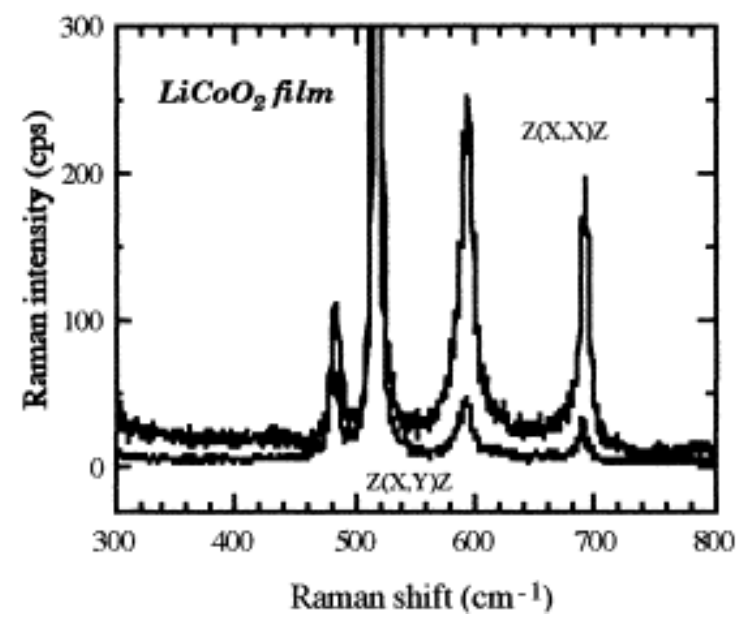

Fig. 1.

Polarized RS spectra of $\mathrm{LiCoO}_{2}$ film grown by PLD method. Peaks around $700 \mathrm{~cm}^{-1}$ are attributed to the presence of $\mathrm{Co}_{3} \mathrm{O}_{4}$ impurities.

\section{Electrochemistry}

In the potential domain 3.0-4.5 V, the charge-discharge curves correspond to the voltage profiles characteristics associated with lithium occupation of octahedral sites, in agreement with previous works[11] and [12]. However, low-temperature synthesized $\mathrm{LiCoO}_{2}$ cathode materials show a lower potential for lithium deintercalationintercalation than the $\mathrm{HT}$-materials prepared at $800^{\circ} \mathrm{C}$. The voltage profile of the cell with carboxylic acid-assisted cathode exhibits a potential slightly lower than for HTsynthesized compound. This is due to the different crystallographic texture and morphology of these two materials. It should be remarked that the fully intercalated phase is not recovered during the first discharge. This could be probably assigned to a kinetic problem especially as the phase $\mathrm{Lix} \mathrm{CoO}_{2}$ is a poor electronic conductor. These studies also demonstrate that the LT-cathode yields significantly superior capacities (150 mAh/g) compared to HT-cathode when discharged to a cut-off voltage of $2.8 \mathrm{~V}$. The improved performance of the $\mathrm{LT}-\mathrm{LiCoO}_{2}$ cell is evident due to the single-phase formation in the entire length of charge-discharge.

Fig. 2a shows the first charge-discharge curves for $\mathrm{Li} \square \mathrm{LiCO}_{0.8} \mathrm{Al}_{0.2} \mathrm{O}_{2}$ cell operated between 2.5 and $4.4 \mathrm{~V}$. The open-circuit voltage of freshly assembled cells were 2.80 to $2.95 \mathrm{~V}$. Replacing a small amount of Co demonstrates higher voltage than the $\mathrm{LiCoO}_{2}$ electrode and slightly decreases the cell capacity. At the cut-off voltage of $4.4 \mathrm{~V}$, the charge gravimetric capacity of the $\mathrm{Li} \square \mathrm{LiCo}_{0.95} \mathrm{Al}_{0.05} \mathrm{O}_{2}$ cell is ca. $150 \mathrm{mAh} / \mathrm{g}$, which is a value similar to that delivered by $\mathrm{LiCoO}_{2}$ cathode. This capacity decrease is more severe when cathode materials $\mathrm{LiCo}_{1-} y \mathrm{Aly} \mathrm{O}_{2}$ with $y>0.10$ were used. A specific gravimetric capacity of $110 \mathrm{mAh} / \mathrm{g}$ was obtained for an $\mathrm{Li} \square \mathrm{LiCo}_{0.75} \mathrm{Al}_{0.25} \mathrm{O}_{2}$ cell. The cells containing $\mathrm{LiCo}_{1}-y \mathrm{AlyO} \mathrm{O}_{2}$ positive electrodes were on average $80 \%$ efficient when 
compared to their expected theoretical capacities. The trends for the $\mathrm{Al}^{3+}$ doped materials showed that lower capacities were obtained with an increase in $y$. This is consistent with the theoretical values, for which a decrease in capacity is expected with an increase in dopant level. The results showed that the cell using the $\mathrm{LiCo}_{0.80} \mathrm{Al}_{0.20} \mathrm{O}_{2}$ powders performed slightly better than the other ones. This means that for $\mathrm{Al}^{3+}$ dopant, the optimum dopant level for gravimetric capacity and life cycle ability would be approximately $y=0.20$. No reason could be given for such a trend. However, the average voltage of the charge characteristics of the $\mathrm{Li} \square \mathrm{LiCo}_{1}-y \mathrm{Aly} \mathrm{O}_{2}$ cells appears to be higher than that of $\mathrm{Li} \square \mathrm{LiCoO}$ cells. The rechargeability of the $\mathrm{Li} \square \mathrm{LiCo}_{1}-\mathrm{AAlyO}_{2}$ cells seems better than $\mathrm{LiCoO}_{2}$ because the lack of the two-phase behavior in the high voltage region. During the first discharge about $10 \mathrm{mAh} / \mathrm{g}$ capacity is irreversible for all the cathodes. It is suggested that the fully charge state appears when $\mathrm{Li}$ ions cannot be extracted from the host matrix because no electrons are removed from either $\mathrm{Al}^{3+}$ or $\mathrm{Co}^{4+}$. Fig. $2 \mathrm{~b}$ displays the plot of the average cell voltage as a function of the $\mathrm{Al}$ content in $\mathrm{LiCo}_{1}-y_{\mathrm{Al}} \mathrm{O}_{2}$. Obviously, adding $\mathrm{Al}$ increases the lithium intercalation voltage. Experimental data from $\mathrm{Li}_{\square} \mathrm{LiCo}_{1}-y \mathrm{Aly} \mathrm{O}_{2}$ cells are compared with values calculated by Ceder et al. [13] assuming an active role of oxygen anion in the electrochemical potential. The authors suggest that the amount of electron transfer to oxygen occurring upon $\mathrm{Li}$ intercalation correlates strongly with the cell voltages.
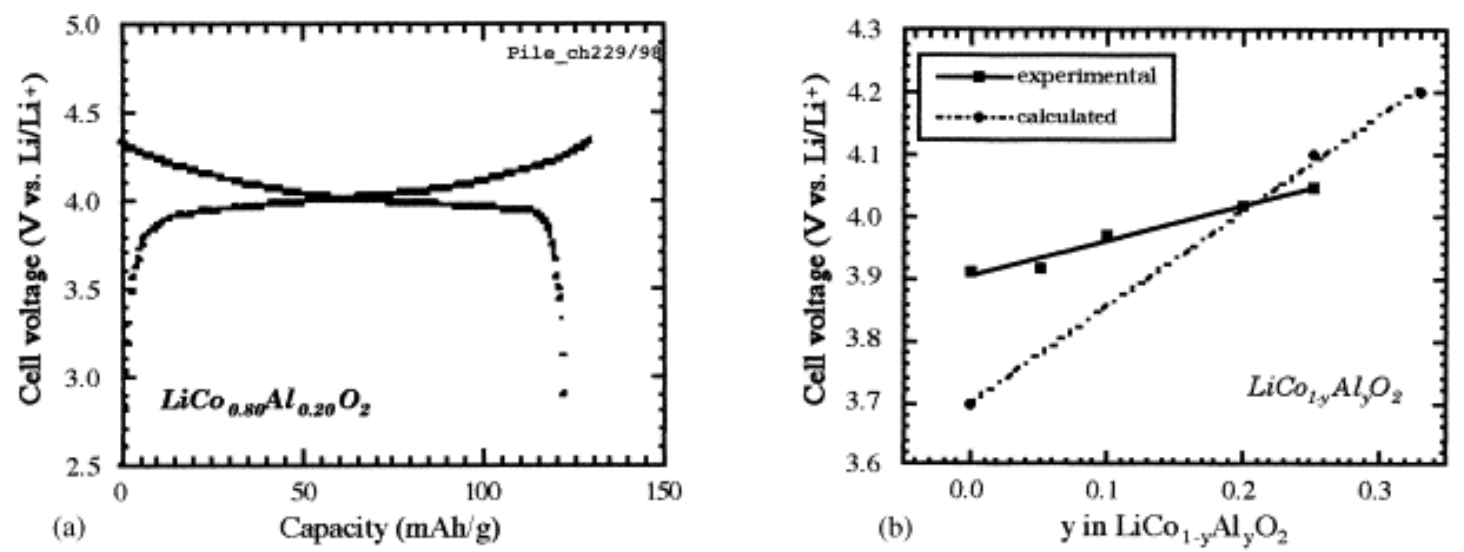

Fig. 2.

(a) Charge-discharge profile of a $\mathrm{Li} \square \mathrm{LiCo}_{0.8} \mathrm{Al}_{0.2} \mathrm{O}_{2}$ cell made with an aluminum doped material.

(b) Variation in the cell voltage as a function of the Al substitution in $\mathrm{LiCo}_{1-} y \mathrm{AlyO}_{2}$.

$\mathrm{LiCoO}_{2}$ films grown onto silicon wafers maintained at $300^{\circ} \mathrm{C}$ were used as cathode materials and tested in lithium microbatteries with $1 \mathrm{M} \mathrm{LiClO}_{4}$ in propylene carbonate as electrolyte. Cyclic voltammetry (CV) measurements show two sets of well-defined 
current peaks observed in the CV diagram corresponding to the oxidation and reduction reactions; they are located at 3.72 and $3.61 \mathrm{~V}$ for the $\mathrm{LiCoO}_{2}$ film. These peaks are slightly shifted toward lower potentials for films grown at lower substrate temperature. These CV features are associated with the redox process of $\mathrm{Co}^{3+}$ to $\mathrm{Co}^{4+}$ and vice-versa, when lithium is extracted from, and inserted into the $\mathrm{Lix} \mathrm{CoO}_{2}$ phase. The redox couple with a mid-peak potential of about $3.66 \mathrm{~V}$ is considered to be a single-phase insertion-deinsertion reaction of lithium ions in $\mathrm{LiCoO}_{2}$. Fig. 3 shows the typical charge-discharge curves of $\mathrm{Li} \square \mathrm{LiCoO}_{2}$ cells using pulsed-laser deposited films grown at substrate temperature in the range $25 \leq T s \leq 300^{\circ} \mathrm{C}$. Electrochemical measurements were carried out at a rate $C / 100$ in the potential range $1.5-4.2 \mathrm{~V}$; as such, the voltage profile should provide a close approximation to the open-circuit voltage (OCV). From these results, we may make some general remarks, that are (i) an initial voltage about $2.15 \mathrm{~V}$ versus $\mathrm{Li}^{\prime} \mathrm{Li}^{+}$was measured for a fresh cell using a PLD $\mathrm{LiCoO}_{2}$ film deposited at $T_{\mathrm{s}}=300^{\circ} \mathrm{C}$, which is lower to that recorded on the cell using crystalline cathode, (ii) the cell voltage curves display the typical profile currently observed for $\mathrm{Lix} \mathrm{CoO}_{2}$ cathodes, (iii) the cell voltage is a function of the structural arrangement in the film and thus depends on the substrate temperature. These potentials slightly increased for films grown at high substrate temperature. This is consistent with many literature data and ensures that at $T_{\mathrm{s}}=300^{\circ} \mathrm{C}$ the material particles are electrochemically active.

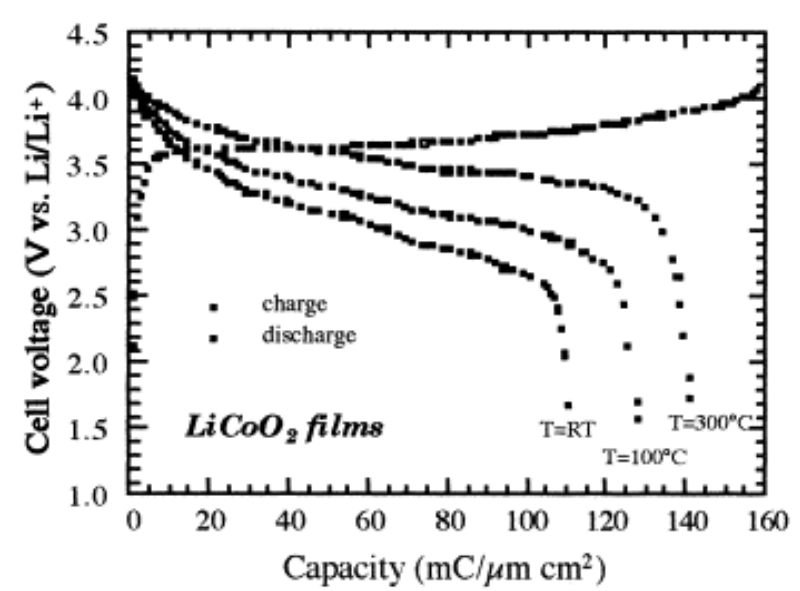

Fig. 3.

Charge-discharge profiles of $\mathrm{Li} / / \mathrm{LiCoO}_{2}$ cells with $1 \mathrm{M} \quad \mathrm{LiClO}_{4} / \mathrm{PC}$ electrolyte. PLD cathode films were grown onto silicon substrate at $25 \leq T_{s} \leq 300^{\circ} \mathrm{C}$ in $P\left(\mathrm{O}_{2}\right)=50$ mTorr.

\section{Conclusion}

Many advances have been made in battery technology in recent years; however, the practicality of systems is highly dependent upon the performance of positive electrodes. Despite the commercial success of $\mathrm{LiCoO}_{2}$, many problems remain in the use of the lithiated cobaltates. The synthesis of new phases, i.e. preparation by chimie 
douce, cationic substitution show various physico-chemical properties associated with improvement of the cycle life of rechargeable lithium batteries. The LT-phases display lower voltage, which could prevent decomposition of the organic electrolyte, and submicron-sized particles, which enhanced the rate capability. The relationship between crystallinity and electrochemical features has been clearly demonstrated for cathode materials prepared by film deposition technique.

\section{Acknowledgements}

The authors would like to thank Mr. M. Lemal for his careful work in performing the XRD measurements. Drs. L. Escobar-Alarcon and E. Haro-Poniatowski are acknowledged for the preparation of PLD films.

\section{References}

1. M.M. Thackeray, W.I.F. David, P.G. Bruce, J.B. Goodenough Mater. Res. Bull., 18 (1983), p. 461

2. T. Ohzuku, A. Ueda, M. Nagayama, Y. Iwakoshi, H. Komori Electrochim. Acta, 38 (1993), p. 1159

3. M. Broussely, F. Perton, P. Biensan, J.M. Bodet, J. Labat, A. Lecerf, C. Delmas, A. Rougier, J.P. Peres

J. Power Sources, 54 (1995), p. 109

4. D. Guyomard, J.M. Tarascon

J. Electrochem. Soc., 139 (1992), p. 937

5. C. Delmas, I. Saadoune

Solid State Ionics, 53-56 (1992), p. 370

6. C. Julien, S.S. Michael, S. Ziolkiewicz

Int. J. Inorg. Mater., 1 (1999), p. 29

7. D. Mazas-Brandariz, M.A. Senaris-Rodriguez, S. Castro-Garcia, M. Camacho-Lopez, C. Julien Ionics, 5 (1999), p. 345

8. L. Escobar-Alarcon, E. Haro-Poniatowski, M. Massot, C. Julien Mater. Res. Soc. Symp. Proc., 548 (1999), p. 223

9. C. Julien

lonics, 5 (1999), p. 351 
10. C. Julien, G.A. Nazri

Mater. Res. Soc. Symp. Proc., 548 (1999), p. 79

11. K. Ozawa

Solid State lonics, 69 (1994), p. 212

12. C. Delmas, I. Saadoune, A. Rougier

J. Power Sources, 43-44 (1993), p. 595

13. G. Ceder, M.K. Aydinol, A.F. Kohan Comput. Mater. Sci., 8 (1997), p. 161

Corresponding author. Tel.: +33-144-274-561; fax: +33-144-274-512 